\title{
Biological, phytochemical, and physico-chemical properties of two commercial Nigella sativa seed oils: A comparative analysis
}

\author{
Muhammad Zakariyyah Aumeeruddy', Zaahira Aumeeruddy-Elalfi', Hudaa Neetoo², Gökhan Zengin³* (D), \\ Bianca Fibrich4, Sunelle Rademan', Analike Blom van Staden ${ }^{4}$, Karina Szuman, Isa Anina Lambrechts ${ }^{4}$, \\ Namrita Lall4, Mohamad Fawzi Mahomoodally* (i) \\ 'Department of Health Sciences, Faculty of Science, University of Mauritius, 230 Réduit, Mauritius \\ ${ }^{2}$ Department of Agricultural and Food Science, Faculty of Agriculture, University of Mauritius, 230 Réduit, Mauritius \\ ${ }^{3}$ Department of Biology, Science Faculty, Selçuk University, 42250 Konya, Turkey \\ 4Department of Plant and Soil Sciences, Faculty of Natural and Agricultural Sciences, University of Pretoria, Pretoria, \\ South Africa
}

Cite this article as: Aumeeruddy MZ, Aumeeruddy-Elalfi Z, Neetoo H, Zengin G, Fibrich B, Rademan S, van Staden AB, Szuman K, Lambrechts IA, Lall N, Mahomoodally MF (2018). Biological, phytochemical, and physico-chemical properties of two commercial Nigella sativa seed oils: A comparative analysis. Istanbul J Pharm 48 (3): 89-99.

\begin{abstract}
This study was designed to evaluate and correlate the biological, phytochemical, and physicochemical properties of two NSS (Nigella sativa seed) oils (N1 and N2). The biological activity was evaluated in terms of antibacterial, antioxidant (nitric oxide scavenging), antielastase, antityrosinase, antimelanogenic, and anticancer activity. Physicochemical properties including colour, total soluble solids (TSS), and density were also investigated. N2 exhibited higher antibacterial, NO scavenging, extracellular antimelanogenic, and anticancer activity against the HeLa cell line compared to N1, which showed higher antityrosinase activity. TPC (total phenolic content) and TFC (total flavonoid content) of N1 were significantly higher than N2 while TTC (total tannin content) was higher in N2. In fact, TTC was strongly correlated (R=1.000) with the antioxidant, extracellular antimelanogenic, and HeLa cell inhibitory activity. To conclude, NSS oil may be considered as a complementary and alternative therapy in the management of infectious and chronic diseases but warrants further in vivo pharmacological validation and toxicological analysis.
\end{abstract}

Keywords: Nigella sativa, biological, phytochemical, physicochemical

\section{INTRODUCTION}

The growing number of bacterial infections and antibiotic resistance have become a major threat to global health, food security, and development. Without effective antibiotics, modern medical treatments including organ transplantations, chemotherapy, and surgeries become much more risky (WHO 2017a). On the other hand, noncommunicable diseases (NCDs) are now the leading cause of death globally, responsible for 40 million deaths each year, equivalent to $70 \%$ of all deaths across the world (WHO 2017b). Many NCDs are associated with an increased oxidative stress which is caused by an imbalance between excess freeradical production and endogenous antioxidant levels in the body (Pham-Huy et al 2008). Among NCDs, cancer is the second leading cause of death, accounting for 8.8 million deaths in 2015 (WHO 2017c).

Besides the exploration of antioxidants and chemotherapeutic drugs in the management of NCDs such as cancer, research on the inhibition of key enzymes in the body for the treatment of NCDs has recently intensified. For instance, inhibition of tyrosinase, a key enzyme involved in melanin biosynthesis, may prevent excess formation and accumulation of melanin in the skin, preventing hyperpigmentation disorders including melasma, freckles, lentigines, and geriatric pigment spots (Ya 
et al 2015; Aumeeruddy et al 2017). In addition, over-enzymatic activity, particularly elastase, is associated with loss of skin elasticity; one of the classical aging characteristics. Elastase breaks down elastin, a constituent of the connective tissue responsible for skin firmness and elasticity (Mathen et al 2014).

Recently, much attention has been focused on the exploration of natural remedies for therapeutic purposes due to their low cost, and because of the association of side effects to synthetic drugs. Among natural resources such as terrestrial and marine plants, animals, and micro-organisms, plants have always been a versatile source of shelter, clothing, food, flavours and fragrances, and not the least, medicines (Gurib-Fakim 2006). In fact, $11 \%$ of the 252 drugs, which are considered as basic and essential by the World Health Organisation, are exclusively of plant origin or synthetic drugs derived from natural precursors (Rates 2001). In addition, phytochemistry has become a field of active interest for drug discovery and formulations through isolation, purification and characterisation of new phytochemicals, the biologically active compounds found in different parts of plants ( Ahmad et al 2013).

Nigella sativa seeds (NSS), also known as black seed (English), çörek otu (Turkish) habat-ul-sauda (Arabic) and kalonji in South Asia, is the black coloured, funnel shaped seeds of the N. sativa plant which belongs to the Ranunculaceae family. The plant is cultivated in various regions such as Southern Europe, North Africa, Middle Eastern Mediterranean and the southern regions of Asia including Syria, Turkey, India, Pakistan, and Saudi Arabia (Gilani et al 2004). NSS is regarded as a valuable traditional remedy and has been found to possess extensive biological properties, including antimicrobial, antioxidant, antiinflammatory, anticancer, antidiabetic, cardioprotective properties amongst others (Ahmad et al., 2013). Nonetheless, due to variations observed among studies because of geographical origin, climatic conditions, variety, agricultural techniques applied, extraction and processing techniques, and storage conditions, further analysis is required to understand the factors responsible for these variations in order to obtain better medicinal products and enhanced therapeutic efficacy. The present study therefore aimed to determine any differences in biological activity of two NSS oils originating from the same country, and correlate the data obtained in relation to their phytochemical composition and physicochemical properties. Biological activity was assessed in terms of antibacterial, antioxidant, antielastase, antityrosinase, antimelanogenic, and anticancer activity.

\section{MATERIALS AND METHODS}

\section{Materials}

Commercially available cold-pressed (expelled) NSS oil (N1) and NSS oil (N2), unspecified regarding its extraction technique, were obtained from shops in Mauritius. The NSS oil samples were stored at room temperature in the dark for the entire duration of the study.

\section{Reagents}

All chemicals and reagents used in the study were of analytical grade and were purchased from reliable firms and institutes. Porcine pancreatic elastase type IV, N-succinyl-(Ala)3-pnitroanilide, Trizma base, XTT cell proliferation kit II, L-ascorbic acid, and Actinomycin D were obtained from Sigma Aldrich, MO, USA. Mushroom tyrosinase, L-tyrosine and koijc acid were obtained from Sigma Aldrich, Johannesburg, RSA. The human cervical adenocarcinoma (HeLa) and human breast adenocarcinoma (MCF-7) cell lines were obtained from the European Collection of Cell Cultures (ECACC, England, UK). Minimum Essential Medium (MEM), trypsin-EDTA, fetal bovine serum (FBS), phosphate buffer saline (PBS), Mueller-Hinton agar (MHA), Mueller-Hinton broth (MHB), and antibiotics were supplied by Thermofisher scientific (Modderfontein, Johannesburg, RSA). Sodium nitroprusside and Griess-Ilosvsy's nitrite reagent were purchased from Merck Millipore, Darmstadt, Germany.

\section{Antibacterial assays}

Disc and well diffusion methods were performed following the guidelines of "The Clinical and Laboratory Standards Institute (CLSI)" (CLSI 2015). The two assays were carried out in parallel and parameters including inoculum level, depth of agar, and size of disc and well, were kept constant. Measurements were carried out in triplicate.

\section{Microorganisms used for antibacterial assay}

Clinical isolates including Proteus sp., Klebsiella sp., Streptococcus sp., Pseudomonas sp., and Escherichia coli were obtained from the Faculty of Science, University of Mauritius, while American Type Culture Collection (ATCC) strains including Escherichia coli ATCC 25922, Proteus mirabilis ATCC 12453, Pseudomonas aeruginosa ATCC 27853, Staphylococcus epidermidis ATCC 35984, and Staphylococcus epidermidis ATCC 14990 were obtained from the Faculty of Agriculture, University of Mauritius. All strains were sub-cultured on Mueller-Hinton Agar $(\mathrm{MHA})$ and grown in Mueller-Hinton broth (MHB) at $37^{\circ} \mathrm{C}$ prior to the day of use.

\section{Disc Diffusion Assay}

One hundred microlitres of bacterial culture, adjusted to 0.5 McFarland standard turbidity scale in MHB, was spread evenly on the surface of MHA plates. Paper discs (5 mm), prepared from Whatmann filter paper, were impregnated with $30 \mu \mathrm{l}$ of NSS oil (undiluted), and placed on the inoculated plates. Discs impregnated with $30 \mu \mathrm{l}$ of streptomycin, cloxacillin, ampicillin, and chloramphenicol, at concentration $1 \mathrm{mg} / \mathrm{ml}$, were used as positive controls, while sterile distilled water was used as the negative control. Plates were incubated at $37^{\circ} \mathrm{C}$ for $24 \mathrm{~h}$ and the diameter of zone of inhibition (ZOI) including that of the discs were measured in $\mathrm{mm}$.

\section{Well Diffusion Assay}

One hundred microlitres of bacterial culture, adjusted to 0.5 McFarland standard turbidity scale in sterile MHB, was spread 
evenly on the surface of MHA plates. Five millimeter diameter wells, sufficiently spaced to avoid overlapping of results, were punched into the surface of the agar using a sterile cork borer followed by addition of $30 \mu$ of NSS oil (undiluted) to each well. Four antibiotics were used as positive control including streptomycin, cloxacillin, ampicillin, and chloramphenicol, at a concentration of $1 \mathrm{mg} / \mathrm{mL}$, while sterile distilled water was used as the negative control. Plates were incubated at $37^{\circ} \mathrm{C}$ for $24 \mathrm{~h}$ and the diameter of the $\mathrm{ZOI}$ including that of the well were measured in $\mathrm{mm}$.

\section{Antioxidant assay}

\section{Nitric oxide scavenging assay}

The nitric oxide (NO) scavenging activity of the samples was measured according to the method described by Mayur et al (2010). The oil samples were prepared by dissolving the oil in ethanol to a starting concentration of 10 $\mathrm{mg} / \mathrm{mL}$. To the top row of a 96 -well plate, $20 \mu \mathrm{L}$ of distilled water and $80 \mu \mathrm{l}$ of the NSS oil sample were added. The NSS oil samples were double diluted to a final concentration ranging from $2000 \mu \mathrm{g} / \mathrm{mL}$ to $15.6 \mu \mathrm{g} / \mathrm{mL}$. Ten millimolar sodium nitroprusside $(50 \mu \mathrm{L})$ was added to all the wells followed by incubation at room temperature under light for $90 \mathrm{~min}$. After incubation, Griess-Ilosvsy's nitrite reagent $(100 \mu \mathrm{L})$ was added to the test wells and distilled water to the colour control wells. The nitrite content was measured at $546 \mathrm{~nm}$ after 5 min incubation in the dark. L-ascorbic acid $(10 \mathrm{mg} / \mathrm{mL})$ and ethanol was used as the positive and negative controls, respectively. The radical scavenging activity was determined as percentage NO radical-scavenging activity which was calculated by the equation: $\quad N O$ radical-scavenging $=[(A C-A S) / A C] \times 100$; where $A C$ is the absorbance of the control solution that contains only NO, and AS is the absorbance of NSS oil samples in NO solution. From these results, the fifty percent inhibitory concentration $\left(\mathrm{IC}_{50}\right)$ was determined using the GraphPad Prism 4.0 program (GraphPad Software, Inc., (A, USA).

\section{Elastase inhibitory activity}

The ability of the NSS oil samples to inhibit porcine pancreatic elastase (PPE) was determined by measuring the release of $p$-nitroaniline from N-succinyl-(Ala)3-p-nitroanilide spectrophotometrically according to the method of Bieth et al (1974) with slight modifications. The reaction mixture contained $100 \mathrm{mM}$ Tris buffer ( $\mathrm{pH} 8.0$ ), $0.5 \mathrm{M} \mathrm{HCl}$, and the test sample (NSS oil and the positive drug control, ursolic acid) which were serially diluted to yield a concentration range of $250-3.13 \mu \mathrm{g} / \mathrm{ml}$. PPE (5 $\mathrm{mM}$ ) was then added and the reaction mixture was incubated for 15 min followed by the addition of $\mathrm{N}$-succinyl-(Ala)3-p-nitroanilide (4 mM). A vehicle control where the sample was replaced by methanol was included as the $100 \%$ rate, and $0 \%$ where the enzyme and substrate were replaced, respectively, by buffer solution. The change in the absorbance of the reaction mixture was measured kinetically at $405 \mathrm{~nm}$ for 15 min using
KC Junior software and a BIO-TEK Power-Wave XS multiwell plate reader. One unit of elastolytic activity is defined as the release of $1 \mu \mathrm{M}$ of $\mathrm{p}$-nitroaniline/min. The concentration of NSS oil at which fifty percent of the enzyme was inhibited $\left(\mathrm{IC}_{50}\right)$ was then calculated.

\section{Tyrosinase inhibitory activity}

The antityrosinase assay was performed according to the method described by Mapunya et al (2011), with few modifications. The NSS oil samples were dissolved in 100 $\mu \mathrm{l}$ DMSO to a $20 \mathrm{mg} / \mathrm{ml}$ stock solution which was diluted with $50 \mathrm{mM}$ potassium phosphate buffer (pH 6.5). In a 96well microtitre plate placed on ice, $30 \mu$ l of tyrosinase enzyme (333 units $/ \mathrm{ml}$ in phosphate buffer $\mathrm{pH} 6.5$ ) was added to $70 \mu$ of varying concentrations of NSS oil, in triplicate. After 5 min of incubation on ice, $110 \mu$ l of substrate $(2 \mathrm{mM}$ L-tyrosine) was added to all the wells. The final concentrations of the sample and positive control (kojic acid) ranged from 1000 to $1.5 \mu \mathrm{g} / \mathrm{ml}$. The optical density (OD) was then measured over a period of $30 \mathrm{~min}$ at a wavelength of 492 $\mathrm{nm}$ using BIO-TEK power Wave XS multi-well plate reader (KC Junior). The fifty percent inhibitory concentration $\left(\mathrm{IC}_{50}\right)$ was then determined by analysing the resulting data using the software GraphPad Prism 4.0 (GraphPad Softwar, Inc. (A, USA).

\section{Melanin inhibitory activity \\ B16F10 Melanoma Cell culture}

Mouse melanocytes (B16F10) were cultured in complete Minimum Essential Eagle's Medium (MEM), containing 10\% FBS, 1.5 $\mathrm{g} / \mathrm{L} \mathrm{NaHCO}_{3}, 2 \mathrm{mM}$ L-glutamate, $10 \mathrm{mg} / \mathrm{ml}$ streptomycin, and $0.25 \mathrm{mg} / \mathrm{ml}$ fungizone.

\section{Measurement of melanin production in Cultured B16F10 Melanoma Cells}

The inhibitory effect of NSS oil on melanin production was determined following the Hill method previously described by Matsuda et al (2005). The cultured B16F10 mouse melanoma cells were trypsinised $(0.25 \%$ trypsin and $0.1 \%$ EDTA at $37{ }^{\circ} \mathrm{C}$ for 5-10 min) and plated into 24-well plates (5 x $10^{4}$ cells/well in $1.5 \mathrm{ml}$ of MEM). The plated cells were incubated for $24 \mathrm{~h}$ at $37^{\circ} \mathrm{C}$ in the $\mathrm{CO}_{2}$ incubator. Following incubation, $500 \mu \mathrm{l}$ of each NSS oil sample (concentration ranging from 500 to $15.6 \mu \mathrm{g} / \mathrm{ml}$ ) was added to each well in duplicate, and the treated 24-well plates were incubated for 3 days at $37^{\circ} \mathrm{C}$ in the $\mathrm{CO}_{2}$ incubator. Test samples and theophylline (negative control) were dissolved in DMSO. The final concentration of DMSO was $5 \%$. The untreated cells were used as the control group.

After incubation, the cultured medium was removed by a pipette and assayed for extracellular melanin as follows: The cultured medium was centrifuged $\left(900 \mathrm{~g}, 20 \mathrm{~min}\right.$ at $\left.4{ }^{\circ} \mathrm{C}\right)$ to separate the cellular components and extracellular components. One millilitre of a mixture of $0.4 \mathrm{M}$ Tris buffer ( $\mathrm{pH}$ 6.8) and ethanol $(9: 1, \mathrm{v} / \mathrm{v})$ was added to $1 \mathrm{ml}$ of the supernatant. The OD of the resulting solution was then measured at 475 
$\mathrm{nm}$, and the amount of extracellular melanin was determined.

To determine the intracellular melanin production, the remaining melanoma cells were washed with CMF-D-PBS (Calcium and Magnesium Free Dulbecco's-Phosphate Buffered Saline) and trypsinised (100 $\mu$ of $0.25 \%$ trypsin and $0.1 \%$ EDTA at $37{ }^{\circ} \mathrm{C}$ for 5-10 min). The cells were digested by the addition of $400 \mu$ of $1 \mathrm{~N} \mathrm{NaOH}$ and then left standing for $16 \mathrm{~h}$ at room temperature. The OD of the resulting solution was then measured at $475 \mathrm{~nm}$, and the amount of intracellular melanin was determined. Melanin inhibition was determined by comparing the OD of the dose dependent treated cells with the untreated cells and the $I C_{50}$ values were determined.

\section{Anticancer activity}

\section{Cell culture}

The human breast adenocarcinoma (MCF-7) and human cervical adenocarcinoma (HeLa) cell lines were maintained in MEM supplemented with 10\% FBS, 1\% antibiotics (100 U/ml penicillin, $100 \mu \mathrm{g} / \mathrm{ml}$ streptomycin), and $250 \mu \mathrm{g} /$ $\mathrm{ml}$ fungizone. The cells were grown statically at $37^{\circ} \mathrm{C}$ in a humidified incubator set at $5 \% \mathrm{CO}_{2}$. Once confluent, the cells were sub-cultured by treating them with trypsin-EDTA (0.25\% trypsin containing $0.53 \mathrm{mM}$ EDTA) for a maximum of $15 \mathrm{~min}$.

\section{MCF-7 and HeLa cell inhibition}

The cytotoxicity of NSS oil was evaluated using the XTT cell proliferation Kit II according to the method of Zheng et al (2001). MCF-7 and HeLa cells ( $1 \times 10^{5}$ cells $\left./ \mathrm{ml}\right)$ were seeded in 96-well microtiter plates, respectively, and allowed to attach for $24 \mathrm{~h}$ at $37{ }^{\circ} \mathrm{C}$ and $5 \% \mathrm{CO}_{2}$. The NSS oil samples were prepared at 20 $\mathrm{mg} / \mathrm{ml}$ stock concentrations in DMSO. The cells were treated with NSS oil at concentrations ranging from 400-3.13 $\mu \mathrm{g} / \mathrm{ml}$ and the positive drug control, actinomycin $\mathrm{D}$, with concentrations ranging between $0.5 \mu \mathrm{g} / \mathrm{ml}$ and $0.002 \mu \mathrm{g} / \mathrm{ml}$. A vehicle control was included where cells were treated with $2 \%$ DMSO. The treated cells were incubated for $72 \mathrm{~h}$ followed by the addition of $50 \mu \mathrm{I}$ XTT to a final concentration of $0.3 \mathrm{mg} / \mathrm{ml}$. The plates were incubated with the viability reagent for $2 \mathrm{~h}$ and the absorbance of the colour complex was measured at $490 \mathrm{~nm}$ with a reference wavelength set at $690 \mathrm{~nm}$ for XTT using KC Junior software and a BIO-TEK Power-Wave XS multi-well plate reader. The assay was performed in triplicate and the fifty percent inhibitory concentration $\left(\mathrm{IC}_{50}\right.$ ) values of the samples were calculated using the GraphPad Prism 4.0 program (GraphPad Software, Inc., CA, USA).

\section{Phytochemical analysis}

\section{Qualitative phytochemical test}

Phytochemical screening for the presence of alkaloids, flavonoids, saponins, phenols, anthraquinones, and steroids was performed using standard protocols (Andzouana and Mombouli 2011; Tiwari et al 2011).

\section{Quantitative phytochemical test}

Total phenolic content (TPC) was measured using the Folin-Ciocalteu method as described by Picot et al (2014). Five hundred microlitres of test sample was mixed with $2500 \mu \mathrm{l}$ Folin-Ciocalteu reagent (ten-fold diluted) and $2000 \mu$ of sodium carbonate solution (7.5\%). The mixture was allowed to stand for 30 min and the absorbance of the solution was measured spectrophotometrically at $760 \mathrm{~nm}$. All determinations were performed in triplicate. TPC was expressed as microgram of gallic acid equivalent (GAE) per gram of sample ( $\mu \mathrm{g}$ GAE/g sample).

The total flavonoid content (TFC) was determined using the aluminum chloride colorimetric method previously described by Picot et al (2014). The reaction mixture containing $2 \mathrm{ml}$ of diluted sample and $2 \mathrm{ml}$ of $2 \% \mathrm{AlCl}_{3}$ solution was allowed to stand at room temperature for 30 min after which the absorbance of the solution was measured spectrophotometrically at $420 \mathrm{~nm}$. All determinations were performed in triplicate and TFC was expressed as $\mu \mathrm{g}$ of rutin equivalent (RE) per $g$ of sample ( $\mu \mathrm{g}$ RE/g sample).

Total tannin content (TTC) was determined using the vanillin$\mathrm{HCl}$ method as previously described by Mak et al (2013). $1 \mathrm{ml}$ of sample was mixed with $5 \mathrm{ml}$ of the reagent mixture $(4 \%$ vanillin in methanol and $8 \% \mathrm{HCl}$ in methanol in the ratio of 1:1). After $20 \mathrm{~min}$, the resulting color change was measured spectrophotometrically at $500 \mathrm{~nm}$. TTC was expressed as $\mu \mathrm{g}$ catechin equivalent (CE) per g sample ( $\mu \mathrm{g}$ CE/g sample).

\section{Physicochemical properties}

Physicochemical properties including colour, TSS, and density were tested. For colour measurement, CIELAB L* $a^{*} b^{*}$ colour parameters were determined using a chromameter (Minolta CR-410, Konica Minolta, Japan), which was placed directly over the samples in petri dishes filled to the brim. $L^{*}$ represents lightness, $a^{*}$ measures the degree of red $\left(+a^{*}\right)$ or green $\left(-a^{*}\right)$ colours and $b^{*}$ parameter indicates the degree of the yellow $\left(+b^{*}\right)$ or blue $\left(-b^{*}\right)$ colours (Boussaid et al 2014). In addition, TSS was measured using a digital hand-held "Pocket" refractometer (ATAGO, PAL-3) with ranges of $0-93^{\circ}$ Brix. Density was measured according to the method described by Kinoo et al (2012) using the formula: Density = Mass of sample/volume of sample. All measurements were done in triplicate.

\section{Statistical analysis}

All data presented in this study was analysed using Microsoft Excel 2010, Minitab version 16, and GraphPad Prism 4.0. One way ANOVA (Tukey's test) was used for evaluation of significant differences between the variables. Pearson's correlation was used to evaluate correlation between the variables. $\mathrm{P}<0.05$ was considered statistically significant.

\section{RESULTS AND DISCUSSION}

\section{Antibacterial activity}

The results of the antibacterial activity of NSS oil are shown in Table 1 and Table 2. The bacterial strains displayed variation 
Aumeeruddy et al. Biological, phytochemical, and physico-chemical properties of two commercial Nigella sativa seed oils: A comparative analysis

Table 1. Antibacterial activity of undiluted samples using disc diffusion assay

\begin{tabular}{|c|c|c|c|c|c|c|}
\hline & N1 & N2 & Streptomycin & Ampicillin & Cloxacillin & Chloramphenicol \\
\hline E.coli (clinical isolate) & $7.3 \pm 0.58^{c}$ & $8.0 \pm 0.0^{c}$ & $10.7 \pm 0.58^{b}$ & $\mathrm{NI}$ & $\mathrm{NI}$ & $21.0 \pm 1.0^{\mathrm{a}}$ \\
\hline E.coliATCC 25922 & $10.0 \pm 1.0^{c}$ & $10.3 \pm 0.58^{c}$ & $25.3 \pm 0.58^{a}$ & $13.0 \pm 0.0^{\mathrm{b}}$ & $\mathrm{NI}$ & $25.7 \pm 0.58^{\mathrm{a}}$ \\
\hline Proteus sp. (clinical isolate) & $8.7 \pm 0.58^{c}$ & $9.0 \pm 0.0^{c}$ & $18.7 \pm 0.58^{\mathrm{a}}$ & $\mathrm{NI}$ & $\mathrm{NI}$ & $15.7 \pm 0.58^{b}$ \\
\hline P. mirabilis ATCC 12453 & $33.0 \pm 1.0^{\mathrm{b}}$ & $\geq 44^{\mathrm{a}}$ & $23.7 \pm 0.58^{e}$ & $20.0 \pm 1.0^{f}$ & $28.7 \pm 0.58^{c}$ & $26.7 \pm 0.58^{d}$ \\
\hline Pseudomonas sp. (clinical isolate) & $7.7 \pm 0.58^{a}$ & $8.0 \pm 1.0^{a}$ & $\mathrm{NI}$ & $\mathrm{NI}$ & $\mathrm{NI}$ & $\mathrm{NI}$ \\
\hline P. aeruginosa ATCC 27853 & $15.3 \pm 0.58^{d}$ & $31 \pm 1.0^{\mathrm{a}}$ & $25.7 \pm 0.58^{b}$ & $15.3 \pm 0.58^{d}$ & $13.7 \pm 0.58^{\mathrm{e}}$ & $23.0 \pm 0.0^{c}$ \\
\hline Klebsiella sp. (clinical isolate) & $8.0 \pm 1.0^{\mathrm{b}}$ & $8.7 \pm 0.58^{b}$ & $16.3 \pm 0.58^{a}$ & $\mathrm{NI}$ & $\mathrm{NI}$ & $8.0 \pm 0.0^{b}$ \\
\hline Streptococcus sp. (clinical isolate) & $19.7 \pm 0.58^{b}$ & $39.7 \pm 0.58^{\mathrm{a}}$ & $\mathrm{NI}$ & $16.0 \pm 1.0^{c}$ & $\mathrm{NI}$ & $21.0 \pm 1.0^{\mathrm{b}}$ \\
\hline S. epidermidis ATCC 35984 & $39.7 \pm 0.58^{b}$ & $\geq 44^{\mathrm{a}}$ & $\mathrm{NI}$ & $12.7 \pm 0.58^{d}$ & $9.0 \pm 1.0^{\mathrm{e}}$ & $24.3 \pm 0.58^{c}$ \\
\hline S. epidermidis ATCC 14990 & $29.7 \pm 0.58^{c}$ & $\geq 44^{\mathrm{a}}$ & $20.7 \pm 0.58^{e}$ & $19.7 \pm 0.58^{e}$ & $38.7 \pm 0.58^{b}$ & $23.7 \pm 0.58^{d}$ \\
\hline
\end{tabular}

Table 2. Antibacterial activity of undiluted samples using well diffusion assay

\begin{tabular}{|c|c|c|c|c|c|c|}
\hline & N1 & N2 & Streptomycin & Ampicillin & Cloxacillin & Chloramphenicol \\
\hline E.coli (clinical isolate) & $\mathrm{NI}$ & $\mathrm{NI}$ & $12.3 \pm 0.58^{b}$ & $\mathrm{NI}$ & $\mathrm{NI}$ & $18.3 \pm 0.58^{\mathrm{a}}$ \\
\hline E.coli ATCC 25922 & $\mathrm{NI}$ & $\mathrm{NI}$ & $28.3 \pm 0.58^{a}$ & $16.3 \pm 0.58^{b}$ & $\mathrm{NI}$ & $29.7 \pm 0.58^{\mathrm{a}}$ \\
\hline Proteus sp. (clinical isolate) & $9.3 \pm 0.58^{d}$ & $11.0 \pm 0.0^{c}$ & $21.7 \pm 0.58^{\mathrm{a}}$ & $\mathrm{NI}$ & $\mathrm{NI}$ & $18.3 \pm 0.58^{b}$ \\
\hline P. mirabilis ATCC 12453 & $23.0 \pm 1.0^{\mathrm{e}}$ & $39.7 \pm 0.58^{\mathrm{a}}$ & $28.3 \pm 0.58^{d}$ & $29.3 \pm 0.58^{c d}$ & $30.0 \pm 0.0^{b c}$ & $31.3 \pm 0.58^{b}$ \\
\hline Pseudomonas sp. (clinical isolate) & $\mathrm{NI}$ & $\mathrm{NI}$ & $\mathrm{NI}$ & $\mathrm{NI}$ & $\mathrm{NI}$ & $\mathrm{NI}$ \\
\hline P. aeruginosa ATCC 27853 & $13.3 \pm 0.58^{d}$ & $23.7 \pm 0.58^{b}$ & $26.3 \pm 0.58^{a}$ & $17.7 \pm 0.58^{c}$ & $16.7 \pm 0.58^{c}$ & $24.7 \pm 0.58^{b}$ \\
\hline Klebsiella sp. (clinical isolate) & $\mathrm{NI}$ & $\mathrm{NI}$ & $17.0 \pm 0.0^{a}$ & $\mathrm{NI}$ & $\mathrm{NI}$ & $9.0 \pm 0.0^{b}$ \\
\hline Streptococcus sp. (clinical isolate) & $11.7 \pm 0.58^{c}$ & $23.0 \pm 1.0^{\mathrm{ab}}$ & $\mathrm{NI}$ & $22.3 \pm 0.58^{b}$ & $\mathrm{NI}$ & $24.7 \pm 0.58^{\mathrm{a}}$ \\
\hline S. epidermidis ATCC 35984 & $38.3 \pm 0.58^{b}$ & $\geq 44 a$ & $\mathrm{NI}$ & $13.7 \pm 0.58^{d}$ & $13.3 \pm 0.58^{d}$ & $30.3 \pm 0.58^{c}$ \\
\hline S. epidermidis ATCC 14990 & $21.7 \pm 0.58^{e}$ & $33.7 \pm 0.58^{b}$ & $23.3 \pm 0.58^{d}$ & $20.3 \pm 0.58^{e}$ & $41.3 \pm 0.58^{a}$ & $27.0 \pm 1.0^{c}$ \\
\hline
\end{tabular}

Table 3. Other biological activities of NSS oil

\begin{tabular}{|c|c|c|c|c|c|c|c|}
\hline \multirow{3}{*}{ Samples } & \multirow[b]{2}{*}{$\begin{array}{c}\text { NO } \\
\text { scavenging }\end{array}$} & \multirow[b]{2}{*}{$\begin{array}{c}\text { Elastase } \\
\text { inhibition }\end{array}$} & \multirow[b]{2}{*}{$\begin{array}{l}\text { Tyrosinase } \\
\text { inhibition }\end{array}$} & \multicolumn{2}{|c|}{ Melanin inhibition } & \multicolumn{2}{|c|}{ Anticancer } \\
\hline & & & & Intracellular & Extracellular & $\begin{array}{c}\text { MCF-7 cell } \\
\text { line inhibition }\end{array}$ & $\begin{array}{c}\text { HeLa cell } \\
\text { line inhibition }\end{array}$ \\
\hline & \multicolumn{7}{|c|}{ IC50 ( $\mu \mathrm{g} / \mathrm{mL})$} \\
\hline N1 & $176.8 \pm 3.2^{\mathrm{a}}$ & NIA & $544.6 \pm 1.915^{b}$ & NIC & NIC & NID & NID \\
\hline L-Ascorbic acid & $66.4 \pm 1.9^{c}$ & NT & NT & NT & NT & NT & NT \\
\hline Ursolic acid & NT & $4.27 \pm 0.65$ & NT & NT & NT & NT & NT \\
\hline Kojic acid & NT & NT & $2.849 \pm 4.469^{a}$ & NT & NT & NT & NT \\
\hline Arbutin & NT & NT & $\mathrm{NT}$ & $99.57 \pm 1.998$ & $99.57 \pm 1.998^{b}$ & & \\
\hline Actinomycin D & NT & NT & NT & NT & NT & $0.0075 \pm 3.9$ & $0.0022 \pm 3.4^{\mathrm{a}}$ \\
\hline $\begin{array}{l}\text { Values represent } n \\
\text { (lowercase) within } \\
\text { A: No inhibition at } \\
\text { B: No inhibition at } \\
\text { C: No inhibition at } \\
\text { D: No inhibition at } \\
\text { NI: No inhibition } \\
\text { NT: Not tested }\end{array}$ & $\begin{array}{l}\text { an of triplicate } \\
\text { lumn means si } \\
\text { e highest conce } \\
\text { e highest conce } \\
\text { e highest conce } \\
\text { e highest conce }\end{array}$ & $\begin{array}{l}\text { standard devi } \\
\text { nificantly diffe } \\
\text { tration tested } \\
\text { tration tested } \\
\text { tration tested } \\
\text { tration tested }\end{array}$ & $\begin{array}{l}\text { ation ( } n=3 \text { ) in } \mu \mathrm{g} / \mathrm{n} \\
\text { rent ( } \mathrm{p} \leftarrow 0.05 \text { ). IC } \\
\text { of } 250 \mu \mathrm{g} / \mathrm{mL} \\
\text { of } 1000 \mu \mathrm{g} / \mathrm{mL} \\
\text { of } 500 \mu \mathrm{g} / \mathrm{mL} \\
\text { of } 400 \mu \mathrm{g} / \mathrm{mL}\end{array}$ & Fifty percent in & oitory concentrati & n, & etter superscript \\
\hline
\end{tabular}


in susceptibility to the tested samples. In general, the ATCC strains were found to be more susceptible compared to the clinical isolates. Overall, N2 was more effective than N1, exerting significantly $(p<0.05)$ greater antibacterial activity against P. mirabilis ATCC 12453, P. aeruginosa ATCC 27853, Streptococcus sp. and S. epidermidis (ATCC 35984 and ATCC 14990) compared to the reference antibiotics tested, which were found to be ineffective against several tested bacteria (Table 1 and Table 2). For instance, 6 out of 10 bacterial strains were resistant to cloxacillin while 4 strains were resistant to ampicillin. On top of that, the Pseudomonas sp. (clinical isolate) was resistant to all 4 antibiotics. The effectiveness of NSS oil against the tested bacteria in the present study is in conformity with the findings of previous studies (Arici et al 2005; Salman et al 2008). However, in contrast to the sensitivity of Klebsiella sp. to NSS as observed in our study, the study of Salman et al (2008) showed that NSS oil was not effective against ten multi-drug resistant strains of $K$. pneumoniae. Other Klebsiella sp. such as K. planticola were also found to be resistant to the oil (Shafi et al 2009). Additionally, resistance to E. coli was observed by Salman et al (2008) in contrast to the findings of the current study. This variation in activity can be due to several factors including geographical regions, plant growing conditions, extraction techniques, processing, refining, and purification of the crude oil which may destroy the antibacterial compounds of the oil.

Comparison of the two antibacterial assays revealed significant differences such that the NSS oil samples displayed significantly greater $\mathrm{ZOI}(\mathrm{p}<0.05)$ against all tested bacteria using the disc diffusion method except Proteus sp. (clinical isolate) for which the well diffusion assay was found to be better (Fig. 1). For instance, no ZOI was observed in well diffusion assay against the two tested E.coli strains, Pseudomonas sp. and Klebsiella sp. while a small ZOI in the range 7.3-10.3 $\mathrm{mm}$ was observed using disc diffusion method. The higher activity of the oil in disc diffusion compared to the well diffusion assay in our study could be due to the direct contact of the disc (impregnated with oil) with the bacteria, indicating a shorter distance for diffusion of the components of the oil through the medium. In contrast, in the well diffusion assay, the bioactive compounds need to diffuse through a longer distance from the bottom of the well to reach the bacteria on the surface of the agar.

\section{Antioxidant activity}

The antioxidant activity of the tested NSS oil in terms of their scavenging activity against $\mathrm{NO}$ radical are shown in Table 3. Among the tested samples, N2 $\left(I_{50}=148.1 \mu \mathrm{g} / \mathrm{ml}\right)$ displayed significantly greater scavenging activity than N1 $\left(I C_{50}=176.8 \mu \mathrm{g} / \mathrm{ml}\right)(p<0.05)$. However, the two NSS oil were found to exhibit significantly lower scavenging activity compared to the positive control, L-Ascorbic acid $\left(\mathrm{IC}_{50}=66.4\right.$ $\mu \mathrm{g} / \mathrm{ml})(\mathrm{p}<0.05)$. A previous study by Zaher et al (2008) observed a lower $I C_{50}$ value of $110 \mu \mathrm{g} / \mathrm{ml}$ for NSS aqueous extract, hence greater scavenging activity compared to the present study. In addition, NSS aqueous extract was found to exhibit an inhibitory effect on NO production by murine macrophages (Mahmood et al 2003). However, it should be highlighted that few studies have investigated the NO radical scavenging activity of NSS compared to other antioxidant assays such as DPPH (2,2-diphenyl-1-picrylhydrazyl) radical scavenging (Goga et al 2012; Haron et al 2014; Feroz and Uddin 2016), indicating the necessity of conducting more antioxidant assays to obtain the complete antioxidant profile of NSS.

\section{Elastase inhibitory activity}

The inhibitory effect of NSS oils on elastase activity are displayed in Table 3. At the highest concentration tested $(250 \mu \mathrm{g} / \mathrm{ml})$, no inhibition was observed in contrast to the positive control, ursolic acid, which displayed an $I C_{50}$ value of $4.27 \mu \mathrm{g} / \mathrm{ml}$. On the contrary, Kacem and Meraihi (2006) found that the essential oil of Algerian NSS showed dosedependent inhibition on human neutrophil elastase. An increase in activity was observed from $410 \mu \mathrm{g} / \mathrm{ml}$ (about $20 \%$ inhibition) to $5800 \mu \mathrm{g} / \mathrm{ml}$ (total inhibition). Therefore, a concentration higher than that used in the present study might show potential antielastase activity which needs to be confirmed by future studies.

\section{Tyrosinase inhibitory activity}

The tyrosinase inhibitory activity of the two NSS oil samples are presented in Table 3. At the highest concentration tested, $1000 \mu \mathrm{g} / \mathrm{ml}, \mathrm{N} 2$ did not show any inhibitory activity. On the other hand, N1 inhibited 50\% of the enzyme at a concentration of $544.6 \mu \mathrm{g} / \mathrm{ml}$, but was less effective compared to the positive control kojic acid $\left(\mathrm{IC}_{50}=2.849 \mu \mathrm{g} / \mathrm{ml}\right)$. Few studies have demonstrated the antityrosinase activity of NSS. For instance, an inhibition of $49.6 \%$ was observed by the chloroform: methanol (2:1) extract of NSS at $500 \mu \mathrm{g} /$ $\mathrm{ml}$ (Subramanian and Sahithya 2016). In addition, Muddathir et al (2017) found that the methanolic NSS extract (500 $\mu \mathrm{g} / \mathrm{ml}$ ) exhibited tyrosinase inhibition of $15.73 \%$ and 17.64 $\%$ to L-tyrosine and L-DOPA, respectively, while no inhibition was observed at $125 \mu \mathrm{g} / \mathrm{ml}$. Interestingly, the study of Sekeroglu et al (2012) revealed a lower active concentration of $50 \mu \mathrm{g} / \mathrm{ml}$, showing a dose-dependent tyrosinase inhibitory activity.

\section{Melanin inhibitory activity}

The $I C_{50}$ values obtained in the melanin inhibition assay are shown in Table 3. The NSS oil samples displayed no inhibition on intracellular melanin synthesis at the highest tested concentration $(500 \mu \mathrm{g} / \mathrm{ml})$. In contrast, although $\mathrm{N} 1$ was ineffective against extracellular melanogenesis at the highest tested concentration $(500 \mu \mathrm{g} / \mathrm{ml})$, a $50 \%$ inhibition was observed by sample $\mathrm{N} 2$ at a concentration of $47.83 \mu \mathrm{g} / \mathrm{ml}$, which was more effective compared to the positive control arbutin $\left(I C_{50}=99.57 \mu \mathrm{g} / \mathrm{ml}\right)$. Compared to previous studies, the antimelanogenic activity of NSS oil observed in the present study was found to be in agreement with that of Lee et al (2011) who found that NSS oil caused a reduction in melanin production up to $86 \%$ at a concentration of 10 
$\mathrm{mg} / \mathrm{ml}$. Although sample N1 showed no antimelanogenic activity, it should be noted that its tyrosinase activity observed in the present study indicates its indirect role as an antimelanogenic agent due the involvement of the tyrosinase enzyme in melanogenesis (Aumeeruddy et al 2017). It is also important to note that NSS is used as an ingredient in various cosmetic skin products including soap, cream, shampoo, and has been found to possess cosmeceutical properties including anti-hair loss, anti-psoriatic, anti-acne vulgaris, anti-vitiligo, and wound healing properties (Sudhir et al 2016; Eid et al 2017).

\section{Anticancer activity}

As shown in Table 3, although NSS oil N1 displayed no anticancer activity on HeLa cells at the highest concentration tested $(400 \mu \mathrm{g} / \mathrm{ml})$, N2 was effective with an $\mathrm{IC}_{50}$ value of $375.2 \mu \mathrm{g} / \mathrm{ml}$. Nonetheless, the positive control actinomycin $\mathrm{D}\left(\mathrm{IC}_{50}=0.0022\right.$ $\mu \mathrm{g} / \mathrm{ml}$ ) showed higher activity compared to N2. The cytotoxicity of NSS against HeLa cells have also been observed by various studies. For instance, the methanolic, n-Hexane, and

\section{Table 4. Qualitative phytochemical compositions of NSS oils}

\begin{tabular}{|lcc|} 
& \multicolumn{2}{c|}{ Samples } \\
\cline { 2 - 3 } Phytochemicals & $\mathrm{N} 1$ & $\mathrm{~N} 2$ \\
\hline Alkaloids & + & + \\
Phenols & + & + \\
Flavonoids & + & + \\
Saponins & + & + \\
Steroids & + & + \\
Anthraquinones & + & + \\
\hline Note: N1: NSS oil sample 1; N2: NSS oil sample 2 & & \\
\hline
\end{tabular}

Table 5. Quantitative phytochemical composition of NSS oils

\begin{tabular}{lccc} 
Sample & $\begin{array}{c}\text { Total phenolic } \\
(\mu \mathrm{g} \mathrm{GAE} / \mathrm{g})\end{array}$ & $\begin{array}{c}\text { Total flavonoid } \\
(\mu \mathrm{g} \mathrm{RE} / \mathrm{g})\end{array}$ & $\begin{array}{c}\text { Total tannin } \\
(\mu \mathrm{g} \mathrm{CE} / \mathrm{g})\end{array}$ \\
\hline N1 & $769.44 \pm 5.63^{\mathrm{a}}$ & $58.56 \pm 1.95^{\mathrm{a}}$ & $754.10 \pm 15.01^{\mathrm{b}}$ \\
$\mathrm{N} 2$ & $530.1 \pm 12.98^{\mathrm{b}}$ & $38.71 \pm 1.65^{\mathrm{b}}$ & $1369.61 \pm 14.82^{\mathrm{a}}$ \\
\hline
\end{tabular}

Values represent mean of triplicate \pm standard deviation $(n=3), N 1$ : NSS oil sample 1; N2: NSS oil sample 2; Different letter superscript within columns means significantly different $(p<0.05)$. CE, Catechin equivalent; $G A E$, Gallic acid equivalent; RE, Rutin equivalent chloroform extracts of NSS were found to display $\mathrm{IC}_{50}$ values of $2.28 \mu \mathrm{g} / \mathrm{ml}, 2.20 \mu \mathrm{g} / \mathrm{ml}$ and $0.41 \mathrm{ng} / \mathrm{ml}$, respectively, inducing apoptosis in HeLa cells (Shafi et al 2009). The ethanol extract was also found to inhibit proliferation and colony formation, and induce apoptosis in HeLa cells. The apoptotic induction was exerted through the release of mitochondrial cytochrome $\mathrm{C}$, increase of the Bax/ $\mathrm{BCl}-2$ ratio, activation of caspases $(3,8$, and 9) and cleavage of poly (ADP-ribose) polymerase. Also, it modulated the expression levels of cell cycle-related proteins such as c-Myc, hTER, cyclin D1, CDK-4, p53, and p21 (Elkady 2012).

On the other hand, the two NSS oils tested in the present study showed no inhibitory effect on MCF-7 cell line at a highest tested concentration of $400 \mu \mathrm{g} / \mathrm{ml}$, which was in disagreement with several studies. For instance, the study of Baharetha et al (2013) revealed that among 12 supercritical carbon dioxide $\left(\mathrm{SC}^{-} \mathrm{CO}_{2}\right)$ extracts, the extract prepared at higher temperature $\left(60^{\circ} \mathrm{C}\right)$ and lower pressure (2500 psi) showed selective antiproliferative activity against MCF-7 cells with an $\mathrm{IC}_{50}$ value of $53.34 \mathrm{\mu g} / \mathrm{ml}$, and caused significant apoptosis in the cell line by activating caspase 3/7 and 8 . Another study (Farah 2005) showed that the ethanolic extract of NSS exerted more potency than the aqueous extract against MCF-7 cells in the presence and absence of $\mathrm{H}_{2} \mathrm{O}_{2}$. In addition, the cytotoxicity of doxorubicin was also enhanced by co-administration with a nanoemulsion of NSS oil (Mahmoud and Torchilin 2013). It is important to highlight that the NO scavenging activity of NSS oil observed in the present study can prevent the reaction of $\mathrm{NO}$ with superoxide $\left(\mathrm{O}_{2}{ }^{-}\right)$to form peroxynitrite (ONOO-), a much more powerful oxidant which can be involved in the aetiology of cancer due to its genotoxicity and damages caused to biomolecules (Pacher et al 2007).

\section{Phytochemical composition}

Preliminary phytochemical screening revealed the presence of all tested phytochemicals in NSS oil including alkaloids, phenols, flavonoids, saponins, steroids, and anthraquinones (Table 4). Regarding the quantitative phytochemical composition (Table 5), variations were observed among the tested samples such that the TPC of N1 (769.44 $\mu \mathrm{g} \mathrm{GAE/g)}$ was found to be significantly greater compared to N2 (530.1 $\mu \mathrm{g} \mathrm{GAE} / \mathrm{g})(\mathrm{p}<0.05)$. A similar pattern was observed for TFC $(\mathrm{N} 1=58.56 \mu \mathrm{g} R / \mathrm{g} ; \mathrm{N} 2=38.71 \mu \mathrm{g} \mathrm{RE} / \mathrm{g})$. In contrast, N1 was found to contain lower TTC $(754.10 \mu \mathrm{g} C E / \mathrm{g})$ compared to

Table 6. Correlation between TPC, TFC, TTC, colour, and the observed biological activities

\begin{tabular}{|lrrrrrc}
\hline Assay & TPC & TFC & TTC & L* $^{*}$ & $\mathrm{a}^{*}$ & $\mathbf{b}^{*}$ \\
\hline NO scavenging activity & -1.000 & -1.000 & 1.000 & -1.000 & 1.000 & 1.000 \\
Tyrosinase inhibitory activity & 1.000 & 1.000 & -1.000 & 1.000 & -1.000 & -1.000 \\
Extracellular antimelanogenic activity & -1.000 & -1.000 & 1.000 & -1.000 & 1.000 & 1.000 \\
HeLa cell inhibitory activity & -1.000 & -1.000 & 1.000 & -1.000 & 1.000 & 1.000 \\
\hline TFC, Total flavonoid content; TPC, Total phenolic content. L* represents lightness, a* measures the degree of red (+a*) or green (-a*) colours \\
and b* parameter indicates the degree of the yellow (+b*) or blue (-b*) colours.
\end{tabular}


N2 (1369.61 $\mu \mathrm{g} \mathrm{CE} / \mathrm{g})$. In fact, a strong positive correlation $(R=1.000)$ was observed between TTC and the antioxidant, extracellular antimelanogenic, and HeLa cell inhibitory activity of NSS oil, while TPC and TFC $(R=1.000)$ were positively correlated with antityrosinase activity (Table 6). Compared with previous studies, the TPC of NSS in the current study was observed to be lower compared to the range 0.96-7.60 mg GAE/g as found by Haron et al (2014) and Lutterodt et al (2010).

These variations could be attributed to the extraction techniques as well as other reasons mentioned previously, resulting in variations in the chemical compositions of the oil. Although the antibacterial, antioxidant, extracellular antimelanogenic, and HeLa cell line inhibitory activity of sample N2 was found to be higher than N1, N2 displayed lower total phenolic and flavonoid content. This might suggest that compounds found in higher concentrations are not necessarily responsible for the total activity. It might be that the different compounds in small

\section{Table 7. Physicochemical properties of NSS oil}

\begin{tabular}{|lccc|}
\hline & & N1 & N2 \\
\hline pH & & ND & ND \\
\hline Color & L* $^{*}$ & $66.48 \pm 0.64^{\mathrm{a}}$ & $60.48 \pm 2.18^{\mathrm{b}}$ \\
& $\mathrm{a}^{*}$ & $9.87 \pm 0.49^{\mathrm{b}}$ & $13.07 \pm 1.30^{\mathrm{a}}$ \\
& $\mathrm{b}^{*}$ & $46.38 \pm 0.19^{\mathrm{b}}$ & $50.42 \pm 2.47^{\mathrm{a}}$ \\
Total soluble solids ( ${ }^{\circ}$ Brix) & & $73.5 \pm 1.14^{\mathrm{a}}$ & $73.3 \pm 0.49^{\mathrm{a}}$ \\
Density $(\mathrm{g} / \mathrm{ml})$ & & $0.85 \pm 0.01^{\mathrm{b}}$ & $0.89 \pm 0.00^{\mathrm{a}}$
\end{tabular}

Values represent mean of triplicate \pm standard deviation $(n=3), N D$ : Not detected; N1: NSS oil sample 1; N2: NSS oil sample 2; (-): not detected; Different letter superscript between columns means significantly different $(p<0.05)$. $L^{*}$ represents lightness, $a^{*}$ measures the degree of red $\left(+a^{*}\right)$ or green $\left(-a^{*}\right)$ colours and $b^{*}$ parameter indicates the degree of the yellow $\left(+b^{*}\right)$ or blue $\left(-b^{*}\right)$ colours.

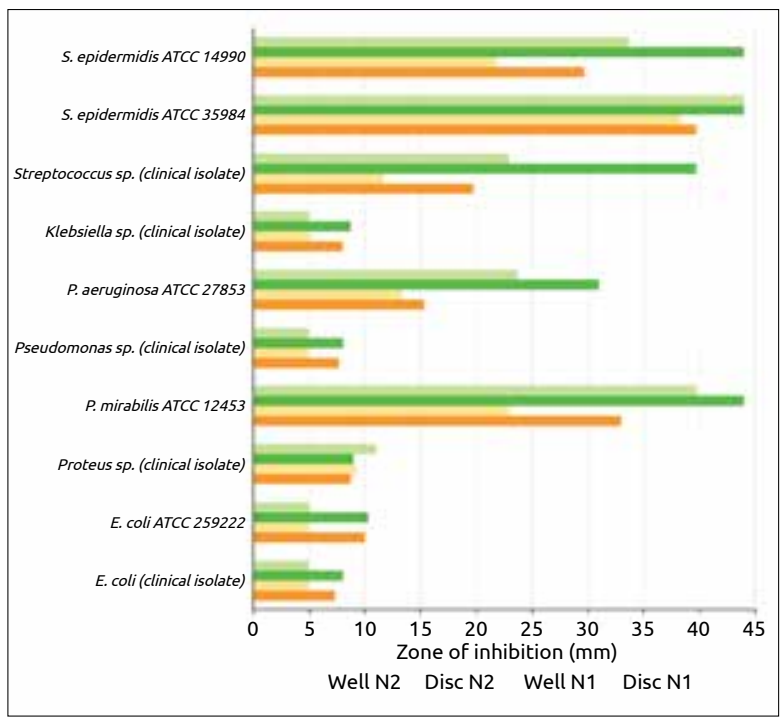

Figure 1. Mean ZOI for disc diffusion and well diffusion assay Diameter of ZOI includes diameter of disc and well (5 mm); ZOI of $5 \mathrm{~mm}$ indicates no inhibition; N1: NSS oil sample 1; N2: NSS oil sample 2 concentrations act synergistically or specific phenolic and flavonoid compounds with stronger bioactivities are present in higher concentration.

For instance, the higher concentration of tannins observed in N2 compared to N1, might explain the higher antibacterial activity of N2. In fact, tannins isolated from several plants have been found to possess significant antimicrobial activity (Ho et al 2001; Jada et al 2014). Moreover, thymoquinone (TQ) has been found to be a major contributor to the biological activities of NSS including antimicrobial activity (Shohayeb and Halawani 2012). In addition, TQ (about $60 \%$ inhibition) and thymohydroquinone (35\% inhibition) at $2 \mu \mathrm{g} / \mathrm{ml}$, were more effective than NSS oil in suppressing melanin production (Lee et al 2011). The mechanisms by which TQ exhibits its anticancer activity against MCF-7 and HeLa cells have also been reported by several studies (Alobaedi et al 2017; Cakir et al 2016; Rajput et al 2013; Woo et al 2011; Yazan et al 2009).

However, it is important to highlight that although TQ has been found to the major contributor to the antioxidant activity of NSS, other constituents, mainly those of the essential oil fraction, including carvacrol, thymol, t-anethole, $\gamma$-terpinene, 4-terpineol, $p$-cymene, $\beta$-pinene, and a-thujene, have also been found to be responsible ( Ahmad and Beg 2014; Burits and Bucar 2000; Kazemi 2014). Additionally, carvacrol was found to be the most bioactive compound in inhibiting human neutrophil elastase with a very low $I C_{50}$ value $(12 \mu \mathrm{M})$, followed by carvone $\left(I_{50}=14 \mu \mathrm{M}\right)$, p-Cymene $\left(I C_{50}=25 \mu \mathrm{M}\right)$, and TQ $\left(I_{50}=30 \mu \mathrm{M}\right)$ (Kacem and Meraihi 2006). In addition, thymohydroquinone was found to display higher tyrosinase inhibitory activity $(68.82 \%$ inhibition at $120 \mu \mathrm{g} / \mathrm{ml}$ ) compared to TQ (8.24\% inhibition at $166.67 \mu \mathrm{g} / \mathrm{ml}$ ) (Lee et al 2011). Therefore, the total bioactivity of NSS is not likely to be due to the presence of one main compound but rather due to its plethora of phytochemicals. These bioactive compounds may act in combination to produce synergistic or additive effect which need to be confirmed by future studies.

\section{Physicochemical properties}

The physicochemical properties of the tested samples including TSS, colour, and density are shown in Table 7. No significant difference was observed in the TSS ( ${ }^{\circ}$ Brix: $\mathrm{N} 1=73.5$; N2=73.3) of the two NSS oil tested ( $p>0.05)$. On the other hand, significant difference was observed in the density of the tested samples such that N2 $(0.89 \mathrm{~g} / \mathrm{mL})$ exhibited a higher density than N1 $(0.85 \mathrm{~g} / \mathrm{mL})(p<0.05)$. The density of NSS oil was found to be close to that reported by the study of Zzaman et al (2014) $(0.93-0.98 \mathrm{~g} / \mathrm{mL})$.

Comparison of the colour of the tested samples revealed that N2 displayed significantly lower $L^{*}$ value, higher $a^{*}$ and $b^{*}$ values $\left(L^{*}=60.48, a^{*}=13.07, b^{*}=50.42\right)$ than $N 1 \quad\left(L^{*}=66.48\right.$, $\left.a^{*}=9.87, b^{*}=46.38\right)(p<0.05)$. This may suggest the presence of more yellow pigments (e.g. carotenoids) in N2, which may 
have contributed to its higher antioxidant activity compared to N1. Compared to other studies, the two NSS oil in the current study displayed higher $L^{*}$ and $a^{*}$ value, and lower $b^{*}$ value than Tunisian and Iranian NSS oil (Cheikh-Rouhou et al 2007). This discrepancy might be due to difference in seed variety or extraction technique employed. In fact, the study of Zzaman et al (2014) showed that screw pressed NSS oil at different temperatures displayed variations in colour. Interestingly, $a^{*}$ and $b^{*}$ values were positively correlated $(R=1.000)$ with the antioxidant, extracellular antimelanogenic, and HeLa cell inhibitory activity, while $L^{*}$ was positively correlated with the antityrosinase activity $(R=1.000)$ (Table 6).

\section{CONCLUSION}

From the present investigation, it was found that NSS oil possess major bioactive phytochemicals and significant biological activities including antibacterial, antioxidant, antityrosinase, antimelanogenic, and anticancer activity (against HeLa cells). We observed variations between the two NSS oil samples such that N2 displayed higher antibacterial, antioxidant, extracellular antimelanogenic, and HeLa cell inhibitory activity compared to N1, which showed higher antityrosinase activity. The higher antibacterial activity of N2 when compared to standard antibiotics in the present study highlights its potential role in effectively slowing the evolution of antibiotic resistance in bacteria. We also found that TTC was positively correlated with most observed activities. The two NSS oil samples also displayed significant variation in physicochemical properties including density and colour whereby the $a^{*}$ and $b^{*}$ values were positively correlated with most observed bioactivities. Nonetheless, it has been argued that in vitro models inherently bear limitations and fail to replicate the precise cellular and metabolic conditions of an organism. Therefore, it is necessary to validate the observed biological activities together with toxicological analysis in vivo and clinically to obtain the therapeutic dose for the treatment and/or management of communicable and noncommunicable diseases.

Peer-review: Externally peer-reviewed.

Author Contributions: Concept - F.M., M.Z.A.; Design - F.M., M.Z.A.; Supervision - F.M., H.N.; Resource - M.Z.A., Z.A.E., H.N., G.Z., B.F., S.R., A.B.v.S., K.S., I.A.L., N.L., M.F.M.; Materials - F.M., M.Z.A., G.Z., B.F., S.R., A.B.v.S., K.S., I.A.L., N.L.; Data Collection and/or Processing - M.Z.A., Z.A.E., H.N., G.Z., B.F., S.R., A.B.v.S., K.S., I.A.L., N.L., M.F.M.; Analysis and/ or Interpretation - M.Z.A., Z.A.E., H.N., G.Z., B.F., S.R., A.B.v.S., K.S., I.A.L., N.L., M.F.M.; Literature Search - All authors; Writing - F.M., M.Z.A.; Critical Reviews - F.M., G.Z., M.Z.A.

Acknowledgements: The authors are thankful to the staff of the Faculty of Science and Faculty of Agriculture, University of Mauritius, for providing assistance to laboratory work.

Conflict of Interest: The authors have no conflict of interest to declare.

Financial Disclosure: The authors declared that this study has received no financial support.

\section{REFERENCES}

- Ahmad A, Husain A, Mujeeb M, Khan SA, Najmi AK, Siddique NA, Damanhouri ZA, Anwar F. (2013). A review on therapeutic potential of Nigella sativa: A miracle herb. Asian Pac J Trop Biomed 3(5): 337-352. [CrossRef]

- $\quad$ Ahmad I, Tripathi J, Manik S, Umar L, JR. (2013). Preliminary Phytochemical Studies of the Miracle Herb of the Century, Nigella sativa L. (Black Seed). Indo Am J Pharm Res 3(4): 3000-3007.

- $\quad$ Ahmad S, Beg ZH. (2014). Mitigating role of thymoquinone rich fractions from Nigella sativa oil and its constituents, thymoquinone and limonene on lipidemic-oxidative injury in rats. Springerplus 3(1): 316. [CrossRef]

- Alobaedi OH, Talib WH, Basheti IA. (2017). Antitumor effect of thymoquinone combined with resveratrol on mice transplanted with breast cancer. Asian Pac J Trop Biomed 10(4): 400-408. [CrossRef]

- Andzouana M, Mombouli JB. (2011). Chemical composition and phytochemical screening of the leaves of Hymenocardiaulmoides and Vitexferruginea. Pak J Nutr 10(12): 1183-1189. [CrossRef]

- $\quad$ Arici M, Sagdic O, Gecgel U. (2005). Antibacterial effect of Turkish black cumin (Nigella sativa L.) oils. Grasas y Aceites 56(4): 259-262. [CrossRef]

- $\quad$ Aumeeruddy MZ, Zengin G, Mahomoodally MF. (2017). A review of the traditional and modern uses of Salvadora persica L.(Miswak): Toothbrush tree of Prophet Muhammad. J Ethnopharmaco/ 213: 409-444. [CrossRef]

- Baharetha HM, Nassar ZD, Aisha AF, Ahamed MBK, Al-Suede FSR, Kadir MOA, Ismail Z, Majid AMSA. (2013). Proapoptotic and antimetastatic properties of supercritical $\mathrm{CO} 2$ extract of Nigella sativa Linn. against breast cancer cells. J Med Food 16(12): 1121-1130. [CrossRef]

- $\quad$ Bieth J, Spiess B, Wermuth CG. (1974). The synthesis and analytical use of a highly sensitive and convenient substrate of elastase. Biochem Med 11(4): 350-357. [CrossRef]

- $\quad$ Boussaid A, Chouaibi M, Rezig L, Hellal R, Donsì F, Ferrari G, Hamdi S. (2014). Physicochemical and bioactive properties of six honey samples from various floral origins from Tunisia. Arab J Chem 11 265-274. [CrossRef]

- $\quad$ Burits M, Bucar F. (2000). Antioxidant activity of Nigella sativa essential oil. Phytother Res 14(5): 323-328. [CrossRef]

- Cakir M, Sakalar C, Sezen S, Aksu H, Kurt B, Canatan H. (2016). Thymoquinone confers higher cytotoxicity against triple negative breast cancer compared to estrogen receptor positive breast cancer through modulation of TNF receptor superfamily genes and P65 activity. Eur J Cancer 61: S138-S139. [CrossRef]

- Cheikh-Rouhou S, Besbes S, Hentati B, Blecker C, Deroanne C, Attia H. (2007). Nigella sativa L.: Chemical composition and physicochemical characteristics of lipid fraction. Food Chem 101(2): 673-681. [CrossRef]

- $\quad$ CLSI (2015). Performance standards for antimicrobial susceptibility testing; Twenty-second informational supplement. CLSI document M100-S22. Wayne, PA: Clinical and Laboratory Standards Institute.

- $\quad$ Eid AM, Elmarzugi NA, Abu Ayyash LM, Sawafta MN, Daana HI. (2017). A Review on the Cosmeceutical and External Applications of Nigella sativa. J Trop Med doi.org/10.1155/2017/7092514. [CrossRef] 
- Elkady Al. (2012). Crude extract of Nigella sativa inhibits proliferation and induces apoptosis in human cervical carcinoma HeLa cells. African Journal of Biotechnology, 11 (64): 12710-12720.

- $\quad$ Farah IO. (2005). Assessment of cellular responses to oxidative stress using MCF-7 breast cancer cells, black seed (N. Sativa L.) extracts and H2O2. Int J Environ Res Public Health 2(3): 411-419. [CrossRef]

- Feroz S, Uddin G. (2016). Phytochemical Analysis, Antimicrobial and Antioxidant Study of Nigella sativa Int J Pharm Chem 2(2): 3643.

- Gilani AUH, Jabeen Q, Khan MAU. (2004). A review of medicinal uses and pharmacological activities of Nigella sativa. Pak J Biol Sci 7(4): 441-445. [CrossRef]

- Goga A, Hasic S, Becirovic S, Cavar S. (2012). Phenolic compounds and antioxidant Activity of extracts of Nigella sativa L. Bull Chemists Technol Bosnia Herzegovina 39: 15-19.

- Gurib-Fakim, A. (2006). Medicinal plants: traditions of yesterday and drugs of tomorrow. Molecular aspects of Medicine $\mathbf{2 7}$ (1): 1-93. [CrossRef]

- Haron H, Grace-Lynn C, Shahar S. (2014). Comparison of Physicochemical Analysis and Antioxidant Activities of Nigella sativa Seeds and Oils from Yemen, Iran and Malaysia. Sains Malaysiana 43(4): 535-542.

- Ho K, Tsai C, Huang J, Chen C, Lin T, Lin C. (2001). Antimicrobial aCtivity of tannin components from Vaccinium vitis-idaea L. J Pharm Pharmacol 53(2): 187-191. [CrossRef]

- Jada MS, Usman WA, Adamu YU. (2014). In vitro Antimicrobial Effect of Crude Tannins Isolated from the Leaf of Annona senegalensis. Int J Biochem Res Rev 4(6): 615-623. [CrossRef]

- Kacem R, Meraihi Z. (2006). Effects of essential oil extracted from Nigella sativa (L.) seeds and its main components on human neutrophil elastase activity. Yakugaku Zasshi 126(4): 301-305. [CrossRef]

- $\quad$ Kazemi M. (2014). Phytochemical Composition, Antioxidant, Antiinflammatory and Antimicrobial Activity of Nigella sativa L. Essential Oil. Journal of Essential Oil Bearing Plants 17(5): 1002-1011. [CrossRef]

- Kinoo MS, Mahomoodally MF, Puchooa D. (2012). Anti-microbial and physico-chemical properties of processed and raw honeys of Mauritius. Advances in infectious Diseases 2(2): 25-36. [CrossRef]

- Lee SY, Lee SM, Heo WB, Kim JG, Kim YH. (2011). Effect of Nigella sativa Oil on Melanogenesis. Journal of the Society of Cosmetic Scientists of Korea 37(4): 319-326.

- Lutterodt H, Luther M, Slavin M, Yin JJ, Parry J, Gao JM, Yu LL. (2010). Fatty acid profile, thymoquinone content, oxidative stability, and antioxidant properties of cold-pressed black cumin seed oils. LWTFood Science and Technology 43(9): 1409-1413. [CrossRef]

- Mahmood MS, Gilani A, Khwaja A, Rashid A, Ashfaq M. (2003). The in vitro effect of aqueous extract of Nigella sativa seeds on nitric oxide production. Phytotherapy Research 17(8): 921-924. [CrossRef]

- Mahmoud SS, Torchilin VP. (2013). Hormetic/cytotoxic effects of Nigella sativa seed alcoholic and aqueous extracts on MCF-7 breast cancer cells alone or in combination with doxorubicin. Cell biochemistry and biophysics 66(3): 451-460. [CrossRef]

- Mak YW, Chuah LO., Ahmad, R., Bhat, R. (2013). Antioxidant and antibacterial activities of hibiscus (Hibiscus rosa-sinensis L.) and Cassia (Senna bicapsularis L.) flower extracts. Journal of King Saud University-Science 25(4): 275-282. [CrossRef]
Mapunya M, Hussein A, Rodriguez B, Lall N. (2011). Tyrosinase activity of Greyia flanaganii (Bolus) constituents. Phytomedicine 18(11): 1006-1012. [CrossRef]

Mathen C, Thergaonkar R, Teredesai M, Soman G, Peter S. (2014). Evaluation of anti-elastase and antioxidant activity in antiaging formulations containing terminalia extracts. Int J Herb Med 2: 9599.

Matsuda H, Hirata N, Kawaguchi Y, Yamazaki M, Naruto S, Shibano M, Taniguchi M, Baba K, Kubo M. (2005). Melanogenesis stimulation in murine B16 melanoma cells by umberiferae plant extracts and their coumarin constituents. Biological and Pharmaceutical Bulletin 28(7): 1229-1233. [CrossRef]

- Mayur B, Sancheti S, Shruti S, Sung-Yum S. (2010). Antioxidant and-glucosidase inhibitory properties of Carpesium abrotanoides L. Journal of Medicinal Plants Research, 4(15): 1547-1553.

- Muddathir A, Yamauchi K, Batubara I, Mohieldin E, Mitsunaga T. (2017). Anti-tyrosinase, total phenolic content and antioxidant activity of selected Sudanese medicinal plants. South African Journal of Botany 109: 9-15. [CrossRef]

- $\quad$ Pacher P, Beckman JS, Liaudet L. (2007). Nitric oxide and peroxynitrite in health and disease. Physiological reviews 87 (1): 315-424. [CrossRef]

- $\quad$ Pham-Huy LA, He H, Pham-Huy C. (2008). Free radicals, antioxidants in disease and health. IJBS, $\mathbf{4}(2): 89$.

Picot MCN, Subratty HA, Mahomoodally FM. (2014). Phytochemical Profile and Antioxidant Properties of Six Medicinal Plants Traditionally Used in the Management of Diabetes in Mauritius. Pharmacologia 5(2): 42-49. [CrossRef]

- $\quad$ Rajput S, Kumar BP, Dey KK, Pal I, Parekh A, Mandal M. (2013). Molecular targeting of Akt by thymoquinone promotes $\mathrm{G} 1$ arrest through translation inhibition of cyclin D1 and induces apoptosis in breast cancer cells. Life sciences $\mathbf{9 3}$ (21): 783-790. [CrossRef]

- $\quad$ Rates SMK. (2001). Plants as source of drugs. Toxicon 39(5): 603613. [CrossRef]

- Salman MT, Khan RA, Shukla I. (2008). Antimicrobial activity of Nigella sativa Linn. seed oilagainst multi-drug resistant bacteria from clinical isolates. Natural Product Radiance $\mathbf{7}(1)$ : 10-14.

Sekeroglu N, Senol FS, Orhan IE, Gulpinar AR, Kartal M, Sener B. (2012). In vitro prospective effects of various traditional herbal coffees consumed in Anatolia linked to neurodegeneration. Food research international 45(1): 197-203. [CrossRef]

Shafi G, Munshi A, Hasan TN, Alshatwi AA, Jyothy A, Lei DK. (2009). Induction of apoptosis in HeLa cells by chloroform fraction of seed extracts of Nigella sativa. Cancer Cell International 9(1): 29. [CrossRef]

- Shohayeb M, Halawani E. (2012). Comparative antimicrobial activity of some active constituents of N. sativa L. World App/ Sci J 20(2): 182-189.

- Subramanian V, Sahithya D. (2016). Preliminary Screening of Selected Plant Extracts for Anti Tyrosinase Activity. Journal of Natural Remedies 16(1): 18-21. [CrossRef]

Sudhir S, Deshmukh V, Verma H. (2016). Nigella sativa Seed, a Novel Beauty Care Ingredient: A Review. International Journal of Pharmaceutical Sciences and Research 7(8): 3185.

- Tiwari P, Kumar B, Kaur M, Kaur G, Kaur H. (2011). Phytochemical screening and extraction: a review. Internationale pharmaceutica sciencia 1(1): 98-106.

- WHO (2017a). Antibiotic resistance. https://www.who.int/newsroom/fact-sheets/detail/antibiotic-resistance 
- WHO (2017b). Noncommunicable diseases. https://www. who.int/news-room/fact-sheets/detail/noncommunicablediseases

- WHO (2017c). Cancer. https://www.who.int/cancer/en/

- Woo CC, Loo SY, GeeV, Yap CW, Sethi G, Kumar AP, Tan KHB. (2011). Anticancer activity of thymoquinone in breast cancer cells: possible involvement of PPAR- $\gamma$ pathway. Biochemical pharmacology 82(5): 464-475. [CrossRef]

- Ya W, Chun-Meng Z, Tao G, Yi-Lin Z, Ping Z. (2015). Preliminary screening of 44 plant extracts for anti-tyrosinase and antioxidant activities. Pakistan journal of pharmaceutical sciences $\mathbf{2 8}(5)$ : 17371744.
Yazan LS, Ng WK, Al-Naqeeb G, Ismail M. (2009). Cytotoxicity of thymoquinone (TQ) from Nigella sativa towards human cervical carcinoma cells (HeLa). Journal of Pharmacy Research Vol 2(4).

- Zaher KS, Ahmed W, Zerizer SN. (2008). Observations on the biological effects of black cumin seed (Nigella sativa) and green tea (Camellia sinensis). Global Veterinaria 2(4): 198-204.

- Zheng Y, Chan W, Chan P, Huang H, Tam S. (2001). Enhancement of the anti-herpetic effect of trichosanthin by acyclovir and interferon. FEBS letters 496(2-3): 139-142. [CrossRef]

Zzaman W, Silvia D, Abdullah W, Yang A. (2014). Physicochemical and quality characteristics of cold and hot press of Nigella sativa $L$ seed oil using screw press. J App/ Sci Res 10(12): 36-45. 